\title{
What Determines Chinese Firms’ Decision on Implementing Voluntary Environmental Schemes?
}

\author{
Jun-Yi Shen ${ }^{1}$, Xiang-Dong Qin ${ }^{2}$ \\ ${ }^{1}$ Faculty of International Studies, Hiroshima City University, Hiroshima, Japan; ${ }^{2}$ School of Economics, Antai College of Economics \\ and Management, Shanghai Jiao Tong University, Shanghai, China. \\ Email: shen@intl.hiroshima-cu.ac.jp, xdqin@sjtu.edu.cn
}

Received May $4^{\text {th }}$, 2011; revised July $6^{\text {th }}$, 2011; accepted July $16^{\text {th }}, 2011$.

\begin{abstract}
Understanding why firms choose to implement voluntary environmental schemes in a large polluted country like China is important for both environmental economists and policy makers. In this paper, we utilize unique plant-level survey data of 270 Chinese firms in manufacturing industry to identify the key determinants of their decisions on certifying ISO 14001 environmental management standard and the Chinese Environmental Label. The empirical results exhibit that while there are a number of factors (e.g., ownership, firm size, target market, and the number of rivals) having similar effects on the certification decisions between the two examined programs, the unique factors that only affect the decision of certifying one program (i.e., ISO 14001 or the Chinese Environmental Label) are also observed.
\end{abstract}

Keywords: Voluntary Environmental Scheme, ISO 14001, Eco-Label, Chinese Firm

\section{Introduction}

In the past decade, the trend towards promoting voluntary action and pollution prevention as opposed to mandatory (command-and-control) environmental regulations that prescribe quantity limits on pollutants had increased as more governments worldwide faced and continue to face limited environmental enforcement budgets [1]. The emerging voluntary approach to pollution abatement becomes more and more popular in recent years. This is because of a growing number of business-initiated actions to change corporate culture and management practices through the introduction of environmental label or eco-label programs and international environmental management system certification programs such as the International Standards Organization (ISO) programs [2]. Eco-labels have been used for over twenty years to provide consumers with information about a product which is characterized by improved environmental performance and efficiency compared with similar products without those labels. The main purpose of promoting eco-label programs is to avoid the possible asymmetric information problem between producers and consumers, because some environmentally friendly products normally have unobservable characteristics [3]. In comparison to ecolabel programs, ISO programs concern the way a firm goes about its production, and notdirectly the results of this production. In other words, they concern processes, and not products — at least, not directly [1]. Among them, the ISO 14001 is an international, voluntary standard for environmental management promoted by the ISO, which formally includes five steps in an environmental management system as environmental policy, planning, implementation and operation, checking and operation, and management review. ${ }^{1}$

In the literature, a number of studies have been undertaken on the determinants of firms' environmental performance and firms' voluntary pro-environmental action [5-18]. Among these studies, [12] employed panel data models to study how environmental innovation by US manufacturing industries responds to changes in pollution abatement expenditures and regulatory enforcement during the period of 1983 to 1992 . They found that environmental innovation responds to increases in pollution abatement expenditures, however, increased monitoring and enforcement activities related to existing environmental regulations do not provide any additional incentive to innovate. [9] examined data on compliance with environmental regulations within the manufacturing sector in Mexico and found that the probability of complying depends on the kind of management practices of the

${ }^{1}$ For more detailed issues on the ISO 14001 management standard, see [4]. 
firm and the level of environmental training. [14] investigated whether firms' characteristics influence their decisions to join the Environmental Protection Agency's voluntary Green Lights program. They reported that contrary to conventional theory, the characteristics of firms do affect their decisions to join Green Lights and commit to a program of investments in lighting efficiency. [11] examined empirically the determinants that led large Japanese manufacturers to voluntary environmental commitment and found that the costs and benefits of voluntary actions to enhance or protect the environment, the capacity to act, as well as the environmental values, beliefs, and attitudes of managers are significant determinants of voluntary environmental commitment.

In addition to the above researches on the factors influencing firms' environmental performance and their voluntary pro-environmental action, we find two studies in the literature pointing to the impact of environmental performance on firm performance. [19] conducted a case study to examine the impact of environmental rating of large pulp and paper, auto, and chlor alkali firms on their stock prices and found that the market generally penalizes environmentally unfriendly behavior. [20] conducted static and dynamic panel data analysis of the impact of environmental performance on the firm's financial performance. They showed that environmental performance has a neutral impact on the firm's financial performance, which is consistent with theoretical work suggesting that firms invest in environmental initiatives until the point where the marginal cost of such investments equals the marginal benefit.

In recent years, China's environmental problem, which is considered as a byproduct of its rapid economic growth, is becoming a well-known issue and receiving more and more attentions from both economists and environmental specialists around the world. Previous studies in the environmental economics literature related to environmental issues of Chinese firms paid a lot of attentions to the financial incentives and endogenous enforcement in China's pollution levy system (e.g., [15]), industrial ownership and environmental performance in China (e.g., [17]), bargaining power of Chinese factories in enforcement of pollution regulation (e.g., [13]), relations among inspections, pollution prices and Chinese environmental performance (e.g., [8]), and Chinese firms' technology development and energy productivity (e.g., [16]). However, the issue on the factors influencing Chinese firms' practice of voluntary environmental schemes (e.g., the ISO 14001 and eco-label) has not been fully studied. For this purpose, a firm-level survey was conducted in 2008 to obtain a better understanding of a firm's motivations, its decision-making procedures and its characteristics vis-à-vis its decision on joining a vol- untary environmental program. We consider two environmental programs here, one is ISO 14001 certification and the other is China Environmental Label (hereinafter referred to as eco-label). Consequently, this paper tries to analyze the determinants that lead Chinese firms to implement ISO 14001 and/or eco-label certifications. More specifically, we provide empirical results regarding what determines a firm's choice as to: 1) whether or not it should introduce a certified environmental management system (i.e., ISO 14001); 2) whether or not it should implement a certification of eco-label (i.e., China Environmental Label).

The paper is organized as follows. Section 2 presents our data and Section 3 discusses our empirical methodology. Our empirical findings are reported and discussed in Section 4. The final section highlights policy implications of the results and provides suggestions for future research.

\section{Data}

To investigate the determinants of Chinese firms' choice of adopting eco-label and ISO 14001 standard, we conducted a firm-level survey in China in 2008. Detailed face-to-face interviews were conducted at 270 firms, which were chosen to represent China's manufacturing industry in a set of categories defined by sector, size class and ownership structure. The majority of the interviews were focused on Yangtze Delta Area, which consists of Shanghai, Zhejiang Province, Jiangsu Province, and Anhui Province, to represent its strong economic performance in China in recent years. ${ }^{2}$ As shown in Table 1, the number of firms from this area is 196, making up $72.59 \%$ of the sample.

In our view, the sample is well balanced among 13 sector categories based on the study of [16]. They are 37 firms in the chemicals sector, 30 in the food and beverage sector, 57 in the machinery, equipment and instruments sector, 21 in the metal processing and products sector, 16 in the nonmetal products sector, 19 in the textile, apparel and leather products sector, 15 in the timber, furniture, and paper products sector, 14 in the medical products sector, 10 in the rubber and plastic products sector, 9 in the electric power sector, 7 in the automobile and related products sector, 4 in the petroleum processing and coking sector, and 31 in other sectors of manufacturing industry. The firms are also evenly distributed along the size scale, with roughly similar numbers in large, medium, and small classes. Size classes are defined by employment ranges, with small firms employing 10 - 199 employees, medium about 200 - 1000 employees and large more than 1000 employees. About 40\% in

\footnotetext{
${ }^{2}$ The GDP share of the Yangtze Delta Area over the whole country is
} about $25.45 \%$ in 2006 , while the population share is about $15.56 \%$ [21]. 
Table 1. Summary of the sample.

\begin{tabular}{|c|c|c|c|c|c|}
\hline Characteristics & $n$ & $\%$ & Characteristics & $n$ & $\%$ \\
\hline Sector & & & Ownership & & \\
\hline Chemicals & 37 & 13.70 & State-owned & 48 & 17.78 \\
\hline Electric power & 9 & 3.33 & Collective-owned & 13 & 4.81 \\
\hline Food and beverage & 30 & 11.11 & Private-owned & 107 & 39.63 \\
\hline Machinery and instruments & 57 & 21.11 & Foreign & 49 & 18.15 \\
\hline Medical products & 14 & 5.19 & Joint-venture & 53 & 19.63 \\
\hline Metal processing and products & 21 & 7.78 & & & \\
\hline Automobile and related products & 7 & 2.59 & Has eco-labeled products & & \\
\hline Nonmetal products & 16 & 5.93 & Yes & 69 & 25.56 \\
\hline Petroleum processing/coking & 4 & 1.48 & No & 201 & 74.44 \\
\hline Rubber and plastic products & 10 & 3.70 & & & \\
\hline Textiles and leather products & 19 & 7.04 & Has ISO 14001 certification & & \\
\hline Timber, furniture, and paper & 15 & 5.56 & Yes & 77 & 28.52 \\
\hline Other sectors & 31 & 11.40 & No & 193 & 71.48 \\
\hline Area & & & Total revenue in 2007 & & \\
\hline Shanghai & 123 & 45.55 & $<10$ million RMB & 33 & 11.11 \\
\hline Zhejiang & 22 & 8.15 & 10 - 30 million RMB & 36 & 13.33 \\
\hline Jiangsu & 31 & 11.48 & 30 - 60 million RMB & 32 & 11.85 \\
\hline Anhui & 20 & 7.41 & 60 - 100 million RMB & 29 & 10.74 \\
\hline \multirow[t]{2}{*}{ Other provinces } & 74 & 27.41 & 100 - 200 million RMB & 26 & 9.63 \\
\hline & & & 200 - 500 million RMB & 32 & 11.85 \\
\hline Listed firm on the stock market & & & 500 - 1000 million RMB & 26 & 9.63 \\
\hline Yes & 63 & 23.33 & >1000 million RMB & 43 & 15.93 \\
\hline No & 207 & 76.67 & No answer & 11 & 4.07 \\
\hline Number of the employees & & & Number of the rivals & & \\
\hline$<200$ & 98 & 36.30 & $<10$ & 95 & 35.19 \\
\hline $200-1000$ & 89 & 32.96 & $11-19$ & 76 & 28.15 \\
\hline$>1000$ & 83 & 30.74 & $>20$ & 99 & 36.67 \\
\hline Total & 270 & 100.00 & Total & 270 & 100.00 \\
\hline
\end{tabular}

the sample is private-owned, while the numbers of stateowned, foreign-owned, and joint-venture firms are roughly the same. In addition, $23.33 \%$ of firms are publicly traded in the two stock markets in China (Shanghai Stock Exchange and Shenzhen Stock Exchange). 259 firms answered their annual sales amount in the year of 2007 in our designated ranges, with roughly. similar share in each category. ${ }^{3}$

In the interview, we asked the respondent whether the firm has any eco-labeled products and whether the firm has the certification of ISO 14001 standard. 69 firms

\footnotetext{
${ }^{3}$ The purpose to ask firms to report their annual sales amount in ranges instead of in amounts is to avoid possible complaints.
}

reported that they had at least one eco-labeled product and 77 firms have already certified the ISO 14001. The number of firms with both certification is 23 , accounting for $8.52 \%$ of the sample.

As for the reasons of the eco-label certification given by those firms with eco-labeled products, 73.91\% (51 firms out of 69) concurred that products with the ecolabel certification would be more easily accepted by consumers, while $40.58 \%$ admitted that they did so because of the government regulation. In addition, there were $52.17 \%$ of the firms with the eco-label certification reported that they regarded eco-labeling as a strategy for promoting the firm's prestige, and $57.97 \%$ answered that 
obtaining an eco-label is to demonstrate the effort for environmental protection made by the firms. The last reason that the certification fee for eco-labeling is not so high was cited by $15.94 \%$ of the sample. With respect to the reasons of ISO 14001 certification, 60 of the 77 firms reported that their purpose was to reduce production costs, 63 of the 77 firms admitted that they wanted to reduce the environmental load caused by their production, and 63 of the 77 firms stated that their purpose was to raise their staffs' environmental consciousness. Additionally, 54.55\% of the firms with the ISO 14001 certification reported that implementing ISO 14001 management system would help them communicate with outside more easily, $75.32 \%$ answered that they did so to increase the firm's credibility, and $62.34 \%$ said that their purpose was to upgrade the firm's prestige. Finally, the number of the firms that cited other reasons (e.g., as a combination with other management systems, etc.) was 11, making up $14.29 \%$ of the ISO 14001 certified firms.

\section{Methodology}

This paper seeks to identify the factors that induce the certifications of eco-label and/or ISO 14001. The firm's decision to choose to certify is described by the following latent variable models.

$$
\begin{aligned}
& \text { Ecolabel }_{i}^{*}=X_{i} \beta+\mu_{i} \\
& \text { ISO } 14001_{i}^{*}=X_{i} \gamma+\mathrm{e}_{i}
\end{aligned}
$$

where Ecolabel and ISO 14001 denote whether a firm has eco-labeled products and whether a firm has ISO 14001 certification, respectively. $X$ represents a matrix of explanatory variables capturing the factors that may affect the certification decision of a firm (see more detailed descriptions of these factors in Table 2). $\beta$ and $\gamma$ are coefficients matrix of $X . i=1,2,3,4, \cdots, 270$ represents each firm, and $\mu$ and e represent the error terms in Equations (1) and (2), respectively. The variables marked with asterisks in the equations are latent variables. They are linked to the observed variables in the following way.

$$
\begin{aligned}
& \text { Ecolabel }_{i}= \begin{cases}1 & \text { a firm has eco-labeled products } \\
0 & \text { otherwise }\end{cases} \\
& \text { ISO } 14001_{i}= \begin{cases}1 & \text { a firm has ISO } 14001 \text { certification } \\
0 & \text { otherwise }\end{cases}
\end{aligned}
$$

The above model can be estimated using a binary probit model if we assume the error terms in Equations (1) and (2) follow the standard normal distribution. It is important to note that the parameters of the model, like those of any nonlinear regression model, are not the mar- ginal effects we are accustomed to analyzing. The computation of the marginal effect of a continuous variable in a probit model is performed in the following way.

$$
\begin{aligned}
& \frac{\partial E[\text { Ecolabel } / X]}{\partial X}=\phi(X \beta) \beta \\
& \frac{\partial E[\text { ISO } 14001 / X]}{\partial X}=\phi(X \gamma) \gamma
\end{aligned}
$$

where $\phi(\cdot)$ is the standard normal density. In this case, the marginal effects are usually evaluated at the sample means of the data. Furthermore, another complication for computing the marginal effect in a binary probit model arises because $X$ will often include dummy variables, as the case in this study. The computation of the marginal effect (ME) of a dummy variable can be done in the following way.

$$
\begin{aligned}
& \mathrm{ME}=\mathrm{P}\left(\text { Ecolabel }=1 \mid \bar{x}_{(d=1)}\right)-\mathrm{P}\left(\text { Ecolabel }=1 \mid \bar{x}_{(d=0)}\right) \\
& \mathrm{ME}=\mathrm{P}\left(\mathrm{ISO} 14001=1 \mid \bar{x}_{(d=1)}\right)-\mathrm{P}\left(\text { ISO } 14001=1 \mid \bar{x}_{(d=0)}\right)
\end{aligned}
$$

where $d$ is a dummy variable and $\bar{x}_{(d)}$ denotes the means of all the other variables in the model.

\section{Results}

Tables $\mathbf{3}$ and $\mathbf{4}$ present results from a probit model of the factors associated with eco-label and ISO 14001 certifications. The robust standard errors of the coefficients are reported in the tables. In addition, we also calculate the marginal effects according to Equations (5)-(8) and report the results in Table 5. The detailed descriptions of the variables are provided in Table 2.

\subsection{Eco-label Certification}

Table 3 indicates the existence of significant correlations between the reasons of eco-label certification admitted by the firms and the certification decision in all cases (models (1-4)). It is important to note that the presented reasons provide different incentives. For example, Accepted_consumer and Promotion_strategy are more likely related to firm's economic incentive, while Environment_protection seems to reflect that firms have a strong motivation to take a pro-environment approach. Whatever the differences of these incentives are, the estimated positive signs of these variables suggest that relative to the omitted reason (i.e., the certification fee for eco-labeling is not so high), a firm motivated by any of these reasons is more likely to choose eco-label certification. Concerning the factor of ownership, Foreign owned and Joint_venture have significantly positive signs in all cases, suggesting that foreign capital participation does have an important effect on the firm's environmental certification decision. This result may attest 
Table 2. Definition of the variables.

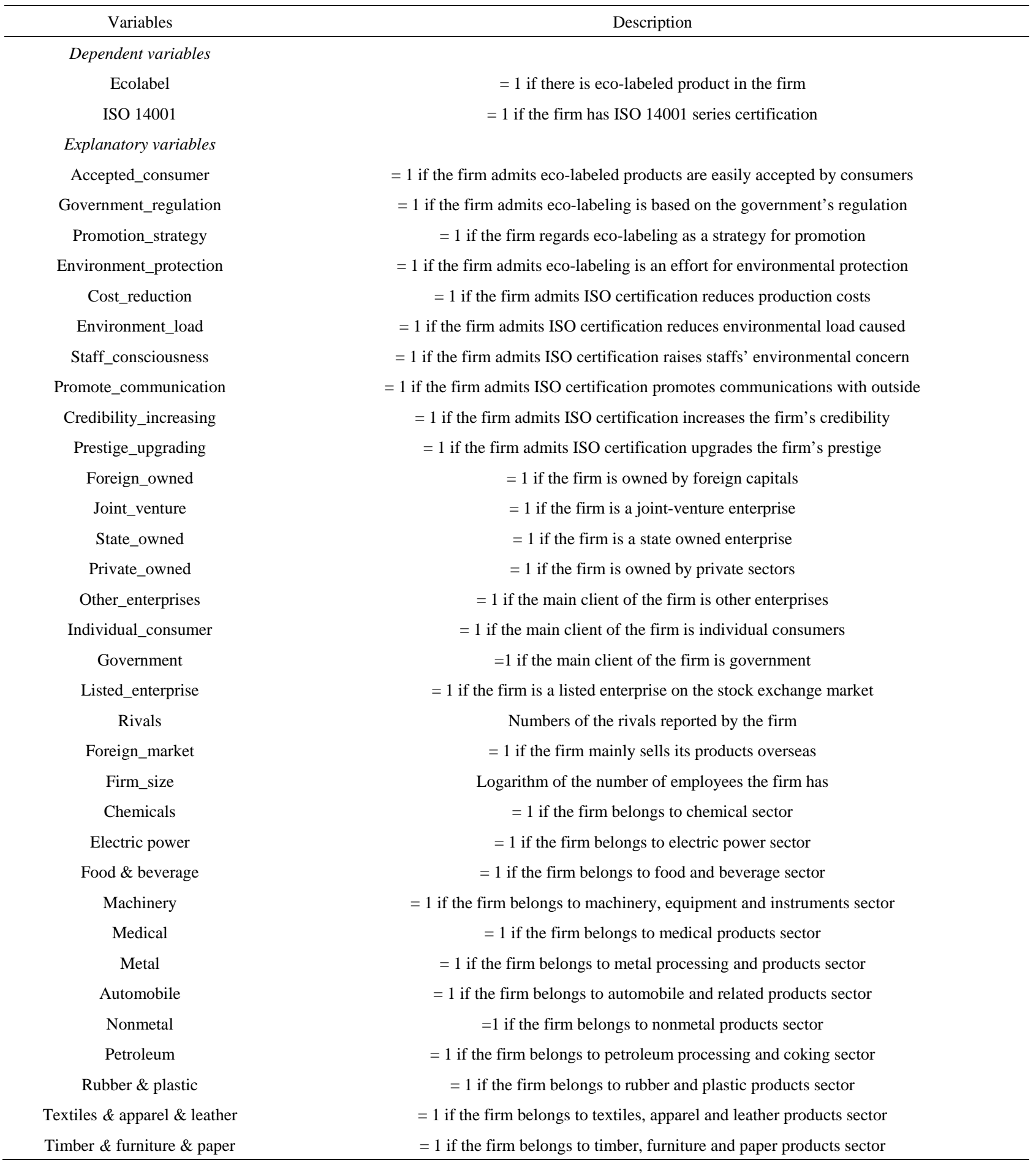

that foreign owners are more eager to increase environmental protection initiatives to secure to prevent discrimination or increase their legitimacy in the eyes of these authorities. ${ }^{4}$ In addition, the results show that the characteristics of firms' client (i.e, other enterprises, in- dividual consumers, and government) do not affect their decisions on certifying eco-label.

Other firm characteristics appear to have a strong impact as well, although the factor that a firm is listed on the stock exchange is not significant. ${ }^{5}$ As expected, the 
Table 3. Factors that affect the eco-label certification (dependent variable: Ecolabel).

\begin{tabular}{|c|c|c|c|c|}
\hline & (1) & $(2)$ & (3) & (4) \\
\hline Constant & $-1.933(0.177)^{* * * *}$ & $-2.879(0.454)^{* * * *}$ & $-5.538(0.976)^{* * * *}$ & $-8.038(1.703)^{* * *}$ \\
\hline \multicolumn{5}{|l|}{ Reasons of certifying eco-label } \\
\hline Accepted_consumer & $1.399(0.343)^{* * *}$ & $1.498(0.381)^{* * *}$ & $1.978(0.467)^{* * *}$ & $2.470(0.755)^{* * *}$ \\
\hline Government_regulation & $1.572(0.520)^{* * *}$ & $1.942(0.599)^{* * *}$ & $1.904(0.849)^{* *}$ & $1.672(0.793)^{* *}$ \\
\hline Promotion_strategy & $0.698(0.389)^{*}$ & $1.001(0.438)^{* *}$ & $1.531(0.698)^{* *}$ & $1.754(0.869)^{* *}$ \\
\hline Environment_protection & $0.786(0.364)^{* *}$ & $0.705(0.392)^{*}$ & $1.303(0.658)^{* *}$ & $1.248(0.599)^{* *}$ \\
\hline \multicolumn{5}{|l|}{ Ownership } \\
\hline Foreign_owned & - & $1.292(0.482)^{* * *}$ & $1.607(0.679)^{* *}$ & $1.787(0.799)^{* *}$ \\
\hline Joint_venture & - & $1.252(0.484)^{* *}$ & $2.283(0.692)^{* * *}$ & $3.130(0.870)^{* * *}$ \\
\hline State_owned & - & $1.071(0.554)^{*}$ & $0.985(0.705)$ & $1.239(0.897)$ \\
\hline Private_owned & - & $0.938(0.774)$ & $1.434(0.767)^{*}$ & $1.155(0.918)$ \\
\hline \multicolumn{5}{|l|}{ Clients } \\
\hline Other_enterprises & - & - & $-0.279(0.373)$ & $-0.736(0.591)$ \\
\hline Individual_consumer & - & - & $0.171(0.351)$ & $0.015(0.398)$ \\
\hline Government & - & - & $0.746(0.432)^{*}$ & $0.264(0.658)$ \\
\hline \multicolumn{5}{|l|}{ Other firm characteristics } \\
\hline Listed_enterprise & - & - & $0.074(0.419)$ & $-0.319(0.496)$ \\
\hline Rivals & - & - & $0.925(0.388)^{* *}$ & $1.680(0.676)^{* *}$ \\
\hline Foreign_market & - & - & $1.234(0.473)^{* * *}$ & $1.139(0.533)^{* *}$ \\
\hline Firm_size & - & - & $0.308(0.087)^{* * *}$ & $0.435(0.124)^{* * *}$ \\
\hline \multicolumn{5}{|l|}{ Sector } \\
\hline Chemicals & - & - & - & $0.242(0.835)$ \\
\hline Electric power & - & - & - & $1.257(1.176)$ \\
\hline Food \& beverage & - & - & - & $1.962(0.933)^{* * *}$ \\
\hline Machinery & - & - & - & $0.605(0.640)$ \\
\hline Medical & - & - & - & $-0.137(0.738)$ \\
\hline Metal & - & - & - & $1.402(0.822)^{*}$ \\
\hline Automobile & - & - & - & $1.975(0.856)^{* *}$ \\
\hline Nonmetal & - & - & - & $2.245(1.159)^{*}$ \\
\hline Petroleum & - & - & - & $3.408(1.398)^{* *}$ \\
\hline Rubber \& plastic & - & - & - & $1.762(0.887)^{* * *}$ \\
\hline Textiles \& apparel \& leather & - & - & - & $0.762(0.539)$ \\
\hline Timber \& furniture \& paper & - & - & - & $-0.433(0.719)$ \\
\hline Observations & 270 & 270 & 270 & 270 \\
\hline Log likelihood & -50.234 & -44.139 & -29.766 & -23.499 \\
\hline Pseudo $\mathrm{R}^{2}$ & 0.608 & 0.655 & 0.663 & 0.725 \\
\hline
\end{tabular}

Notes: ${ }^{* * *},{ }^{* *}$ and ${ }^{*}$ denote statistical significance at $1 \%, 5 \%$ and $10 \%$ levels, respectively. Numbers in parentheses are robust standard errors.

number of rivals is positively correlated with the certification decision, indicating that the more bruising the competition a firm faces, the more likely it certifies ecolabel to distinguish its product from others. Foreign market is positive and significant, suggesting that exportoriented firms are more inclined to have eco-label certification. According to [11], this may occur because foreign consumers tend to be less able to monitor the per- 
Table 4. Factors that affect the ISO 14001 series certification (dependent variable: ISO14001)

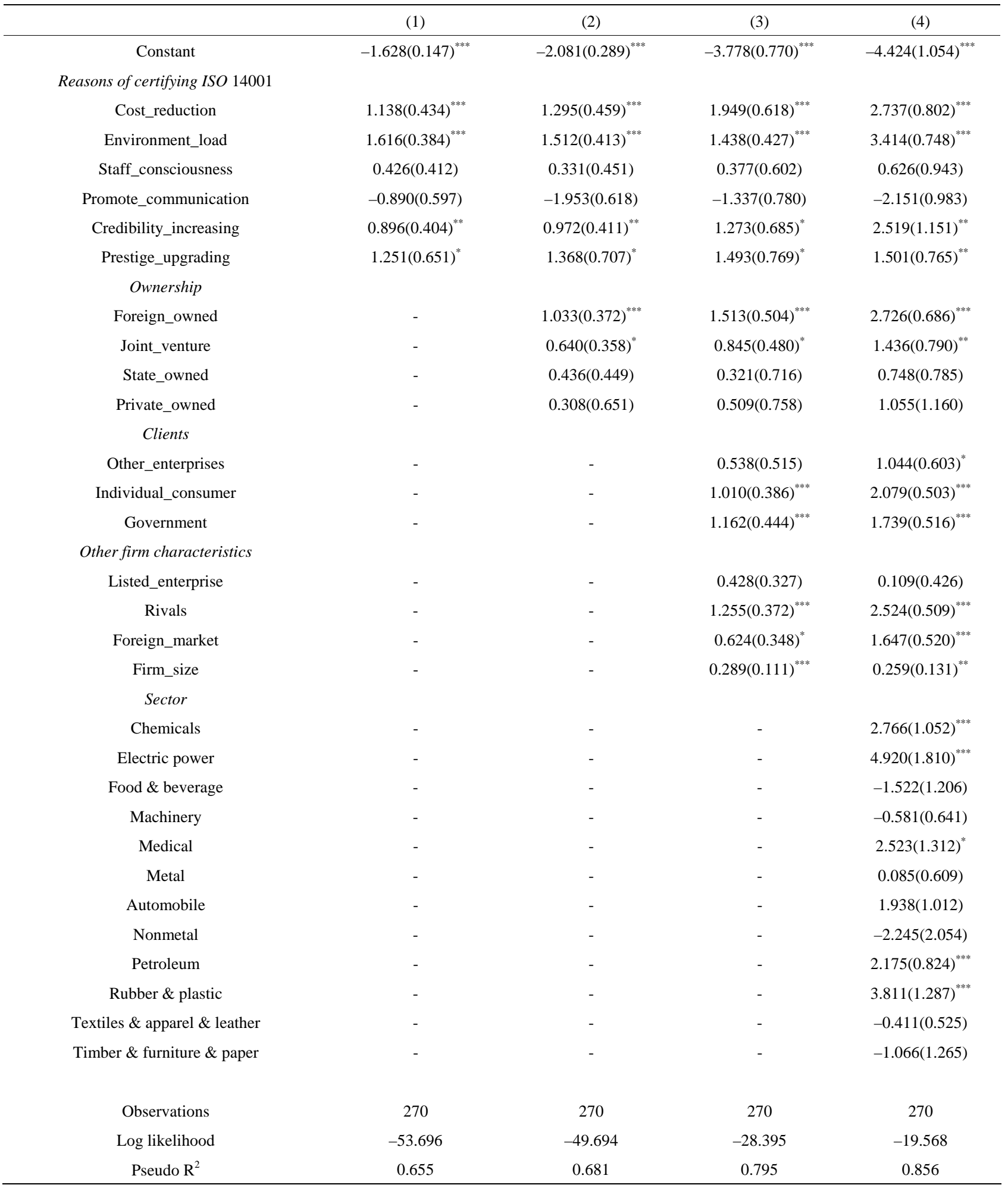

Notes: $^{* * *},{ }^{* *}$ and ${ }^{*}$ denote statistical significance at $1 \%, 5 \%$ and $10 \%$ levels, respectively. Numbers in parentheses are robust standard errors.

formance of the facility or firm, as a result, more visible signs of environmental commitment such as having a certified eco-label may legitimize their reason for doing business with the firm. In addition, there is a significantly 
Table 5. Marginal effects of the factors on the eco-label and ISO 14001 series certifications.

\begin{tabular}{|c|c|c|}
\hline & Eco-label certification & ISO14001 certification \\
\hline \multicolumn{3}{|l|}{ Reasons of certifying eco-label } \\
\hline Accepted_consumer & $0.168^{* * * *}$ & - \\
\hline Government_regulation & $0.070^{* * * *}$ & - \\
\hline Promotion_strategy & $0.067^{*}$ & - \\
\hline Environment_protection & $0.025^{* *}$ & - \\
\hline \multicolumn{3}{|l|}{ Reasons of certifying ISO 14001} \\
\hline Cost_reduction & - & $0.687^{* * *}$ \\
\hline Environment_load & - & $0.701^{* * *}$ \\
\hline Staff_consciousness & - & 0.068 \\
\hline Promote_communication & - & -0.080 \\
\hline Credibility_increasing & - & $0.545^{* *}$ \\
\hline Prestige_upgrading & - & $0.263^{*}$ \\
\hline \multicolumn{3}{|l|}{ Ownership } \\
\hline Foreign_owned & $0.062^{* *}$ & $0.696^{* * * *}$ \\
\hline Joint_venture & $0.219^{* *}$ & $0.196^{*}$ \\
\hline State_owned & 0.022 & 0.171 \\
\hline Private_owned & 0.016 & 0.185 \\
\hline \multicolumn{3}{|l|}{ Clients } \\
\hline Other_enterprises & -0.005 & $0.059^{*}$ \\
\hline Individual_consumer & 0.000 & $0.332^{* * *}$ \\
\hline Government & 0.001 & $0.378^{* * *}$ \\
\hline \multicolumn{3}{|l|}{ Other firm characteristics } \\
\hline Listed_enterprise & -0.001 & 0.009 \\
\hline Rivals & $0.085^{* *}$ & $0.266^{* * *}$ \\
\hline Foreign_market & $0.015^{* *}$ & $0.165^{* *}$ \\
\hline Firm_size & $0.005^{* * * *}$ & $0.021^{* *}$ \\
\hline \multicolumn{3}{|l|}{ Sector } \\
\hline Chemicals & 0.001 & $0.078^{* *}$ \\
\hline Electric power & 0.032 & $0.082^{*}$ \\
\hline Food \& beverage & $0.090^{* *}$ & -0.052 \\
\hline Machinery & 0.004 & -0.029 \\
\hline Medical & -0.001 & $0.049^{*}$ \\
\hline Metal & $0.037^{*}$ & 0.000 \\
\hline Automobile & $0.137^{*}$ & 0.038 \\
\hline Nonmetal & $0.164^{* *}$ & -0.052 \\
\hline Petroleum & $0.625^{* *}$ & $0.049^{* * *}$ \\
\hline Rubber \& plastic & $0.083^{*}$ & $0.051^{* *}$ \\
\hline Textiles \& apparel \& leather & 0.002 & -0.005 \\
\hline Timber \& furniture \& paper & -0.001 & -0.060 \\
\hline
\end{tabular}

Notes: ${ }^{* * *},{ }^{* *}$ and ${ }^{*}$ denote statistical significance at $1 \%, 5 \%$ and $10 \%$ levels, respectively.

positive correlation between the certification decision and firm size that is described by the logarithm of the number of employees. ${ }^{6}$ This result may be plausible because larger firms usually enjoy economies of scale in 
implementing certification. Finally, sector effect on the decision of eco-label certification is presented in the results. We find significant effect in six sectors (i.e., food and beverage, metal processing and products, automobile and related products, nonmetal products, petroleum processing and coking, and rubber and plastic products), and no significant effect in other sectors.

\subsection{ISO 14001 Certification}

Table 4 presents several similar results as those in Table 3. Among the six designated reasons of certifying ISO 14001 management standard, four of them (i.e., Cost reduction, Environment_load, Credibility_increasing, and Prestige_upgrading) exhibit strong correlation with the certification decision, while there seem no significant effects of raising staffs' environmental consciousness and promoting communications with outside on the decision of ISO 14001 certification. It is again shown that foreign-owned and joint-venture enterprises are significantly more likely to implement ISO14001 certification. This result is consistent with that of [17] that foreign and joint-venture firms behave better than the Chinese firms in environmental protection, but different from that of [11] suggesting foreign ownership has no significant effect on Japanese firms' decision of ISO14001 certification. The ISO 14001 certification is, as expected, signifi-

${ }^{4}$ In comparison to our explanation, another view explained by [11] is that foreign owners may be less willing to contribute to the social well-being of the country in which the facility is located and, as a result less inclined to invest in environmental protection above the level of required regulation. However, our results do not support this point of view. This may occur because in comparison to the case in Japan, a large share of the products produced by most foreign-owned and joint-venture firms in China is directly exported abroad. Consequently, the characteristics of their products including the pro-environmental factor should meet what foreign consumers require.

${ }^{5}$ Whether a firm is listed on a stock exchange is used to proxy shareholder pressure here. According to [1], the pressures that shareholders exert over a firm arise as a result of discontent with environmental fines which lower profits, and disillusionment with progress toward environmental goals and with difficulties in raising new capital or attracting new investors due to poor environmental performance. Therefore, they postulated that firms that are listed on a stock exchange are more likely to feel such pressures and, as a result, be more likely to intensify their environmental initiatives in order to gain favor with or maintain their relations with shareholders. However, our results do not support their postulation in both eco-label and ISO 14001 certification decisions (see the variable of Listed_enterprise in Tables 3 and 4). In our view, a possible explanation is that relative to the environmental performances of the listed firms, most of Chinese investors in the stock market pay much more attention to the revenues and profits of the firms. Therefore, as a result, unlike their foreign counterparts, the listed firms in China may not feel so much pressure of environmental issues from the shareholders.

${ }^{6}$ We dropped the variable related to a firm's annual sales amount that could also be considered to proxy firm size in our final estimation. This manipulation is based on two considerations. First, the high correlation between a firm's annual sales amount and the number of employees (0.623) may cause a possible multicollinearity problem. Second, this variable is not significant in both cases of eco-label and ISO 14001 even we dropped the variable of number of employees in the model. cantly and positively correlated with the number of rivals and foreign market orientation. In addition, same as that in the certification of eco-label, there seems also to have economies of scale in the ISO 14001 certification processes because of the significantly positive sign of Firm size, which is consistent with the results in [5] and [11] that larger firms are more likely to undertake voluntary environmental actions.

Several different results between the eco-label and ISO 14001 certifications are found in the following determinants. First, the characteristics of firms' client are important in the case of ISO 14001. Firms targeting at individual consumers and/or government are more likely to certify ISO 14001. In addition, Other_enterprises becomes significant at $10 \%$ level if sector dummies are controlled in the model (see the last column in Table 4). Furthermore, firms belonging to the sectors of petroleum processing and coking or rubber and plastic products are more willing to certify ISO 14001, which is the same as those in the eco-label case. However, four significant sector dummies (i.e., Food \& beverage, Metal, Automobile, and Nonmetal) are no longer significant in the ISO 14001 case. Instead, firms in the sectors of chemical, electric power, and medical products are more likely to undertake the ISO 14001 certification.

\subsection{Marginal Effects}

The estimated marginal effects of each determinant of the eco-label and ISO 14001 certifications are summarized in Table 5. From the table, we can see that among the reasons explaining both certifications, Accepted consumer has the highest marginal effect on the probability of choosing to certify eco-label, while Environment_load and Cost_reduction are the two largest effects in the ISO 14001 certification. It may be plausible for the former because eco-label is usually regarded as the symbol of presenting the product's pro-environment characteristics to consumers. In other words, whether or not the product with the label can be accepted by consumers is a crucial incentive for a firm choosing to seek eco-label certification. In contrast, since ISO 14001 is an international voluntary standard for environmental management systems, firms' decision to undertake the certification of it normally depends on how strong their incentives in raising the level of the environmental management are. Consequently, it is not surprising that trying to mitigate the environmental load caused by the firms and reducing their production cost become the largest two factors influencing the ISO 14001 certification decision.

Some determinants affect more the ISO 14001 certification decision than those in the eco-label case. For example, the effect of foreign-owned firm on the ISO 14001 certification decision (i.e., 0.696 ) is approximately 
10 times larger than that on the eco-label certification (i.e., 0.062). The similar result is also found in the factor of foreign market orientation. The marginal effect of the variable foreign_market on the ISO 14001 certification is 0.165 , which is exactly 10 times larger than 0.015 in the eco-label case. These findings may be explained by the fact that ISO 14001 is more of an international standard, while the eco-label is a Chinese certificate. So firms with international elements tend to adopt more of the ISO 14001 certification. In Addition, there is no big difference between the effects of joint-venture firm on the choice probabilities of both certifications ( 0.219 in the eco-label case vs. 0.196 in the ISO 14001 case). Although the factor of firms' main clients is not significant in the eco-label case, individual consumer and government orientations affect similarly on the probability of undertaking the ISO 14001 certification, both of which are larger than that of Other_enterprises. Furthermore, the effects of the number of rivals and firm size on choice probability of the ISO 14001 certification are, respectively, about 3 times and 4 times as those in the eco-label case.

With regards to the effect of those significant sector dummies on the certification decision, we find a big difference in the eco-label case. The ratios of the probability of certifying eco-label by firms in petroleum processing and coking sector to those firms in other sectors are approximately 4 for Petroleum vs Nonmetal and Automobile, 7 for Petroleum vs Food \& beverage, and 17 for Petroleum vs Metal, respectively. In comparison to these large ratios, the differences in the ISO 14001 case are almost negligible.

\section{Conclusions}

Empirical investigation on the determinants of implementing voluntary environmental schemes at the plant level is scarce in China. To shade more light on this subject, we conducted a firm-level survey and apply the data to study the factors influencing Chinese firms' decision to conduct the ISO 14001 and/or China Environmental Label certifications. Our results exhibit several similar evidences between the factors affecting the decisions of these two certifications. First, in comparison to their Chinese counterparts, foreign-owned and joint-venture firms are more likely to use the certifications. Second, the number of rivals a firm has is positively correlated to its decision on the certifications. Third, foreign market oriented firms are more willing to implement the certifications. Fourth, firm size defined by the number of employees a firm has plays a significant role in determining its choice of different certifications. Fifth, firms in the sectors of petroleum processing and coking or rubber and plastic products are more likely to certify both ISO
14001 standard and eco-label. Sixth, whether or not a firm is listed on a stock exchange is not a significant factor in both cases. Besides the above mentioned similarities, it is important to emphasize that we also find a number of differences in the determinants of these two certifications. First, the factor of a firm's main client significantly affects the decision of the ISO 14001 certification, but not in the eco-label case. Second, sector effect on a firm's certification decision is different in the certifications of ISO 14001 and eco-label. Finally, except for the sector effect, other determinants influencing the ISO 14001 certification have higher marginal effects than those corresponding factors affecting the eco-label certification.

Despite the potential problem such that our sample size may not be large enough to ensure robust estimates, our results presented in this paper have a number of interesting policy implications for Chinese decision makers. First, government policy makers can benefit from the fact that the decisions of firms choosing to implement voluntary environmental schemes are influenced by the above specified reasons other than regulation. Consequently, government can provide incentives based on these reasons to promote voluntary action and pollution prevention as an alternative to mandatory environmental regulations. By offering appropriate incentives, programs such as ISO 14001 and China Environmental Label can bring win-win benefits to firms, consumers, and government. Second, recognizing that various characteristics of firms affect their decision makings in undertaking voluntary environmental programs can help government design more flexible policies than traditional regulations such as tax and command-and-control mandates. Third, acknowledging that firms in different sectors have different underling motivations in certifying ISO 14001 and/or eco-label, Chinese government may form specified environmental policies based on sector specifications, which as a result could be more effective than the current undifferentiated policies in China.

Finally, the present study is suggestive of two areas for further research. First, it should be noted that the results and findings are based on firms mostly located in the Yangtze Delta Area. Therefore, future studies may include firms in other areas of China, which in turn could help to ensure the validity of these findings. Second, various financial data other than annual sales amount, which may also be important in determining firms' decision of implementing voluntary environmental schemes, are not included in the present study due to the fact that most surveyed firms refused to reveal the information. We leave this issue as an open challenge and expect a greater effort to overcome it in follow up studies. 


\section{REFERENCES}

[1] I. Henriques and P. Sadorsky, "Environmental Management Systems and Practices: An International Perspective,” In: N. Johnstone, Ed., Environmental Policy and Corporate Behavior, Edward Elgar Publishing, Northampton, USA, 2007, pp. 34-87.

[2] ISO, "The Integrated Use of Management System Standards," International Standards Organization, 2008.

[3] J. Shen and T. Saijo, "Does Energy Efficiency Label Alter Consumers' Purchase Decision? A Latent Class Approach on Shanghai Data," Journal of Environmental Management, Vol. 90, No. 11, 2009, pp. 3561-3573. doi:10.1016/j.jenvman.2009.06.010

[4] R. Starkey, "Standardization of Environmental Management Systems: ISO 14001, ISO 14004 and EMAS,” In: R. Welford, Ed., Corporate Environmental Management 1: Systems and Strategies, 2nd Edition, Earthscan, London, 1998, pp. 61-89.

[5] S. Arora and T. Cason, "An Experiment in Voluntary Environmental Regulation: Participation in EPA's 33/50 Program," Journal of Environmental Economics and Management, Vol. 28, No. 3, 1995, pp. 271-286. doi:10.1006/jeem.1995.1018

[6] W. B. Gray and M. E. Deily, "Compliance and Enforcement: Air Pollution Regulation in the US Steel Industry," Journal of Environmental Economics and Management, Vol. 31, No. 1, 1996, pp. 96-111. doi:10.1006/jeem.1996.0034

[7] E. Helland, "The Enforcement of Pollution Control Laws: Inspections, Violations, and Self-Reporting," The Review of Economics and Statistics, Vol. 80, No. 1, 1998, pp. 141-153. doi:10.1162/003465398557249

[8] S. Dasgupta, B. Laplante, N. Mamingi and H. Wang, "Inspections, Pollution Prices, and Environmental Performance: Evidence from China," Ecological Economics, Vol. 36, No. 3, 2001, pp. 487-498. doi:10.1016/S0921-8009(00)00249-4

[9] L. Gangadharan, "Environmental Compliance by Firms in the Manufacturing Sector in Mexico,” Ecological Economics, Vol. 59, No. 4, 2006, pp. 477-486. doi:10.1016/i.ecolecon.2005.10.023

[10] M. Khanna, "Non-Mandatory Approaches to Environmental Protection,” Journal of Economic Surveys, Vol. 15, No. 3, 2001, pp. 291-324. doi:10.1111/1467-6419.00141

[11] M. Nakamura, T. Takahashi and I. Vertinsky, "Why Japa- nese Firms Choose to Certify: A Study of Managerial Responses to Environmental Issues,” Journal of Environmental Economics and Management, Vol. 42, No. 1, 2001, pp. 23-52. doi:10.1006/jeem.2000.1148

[12] S. B. Brunnermeier and M. A. Cohen, "Determinants of Environmental Innovation in US Manufacturing Industries," Journal of Environmental Economics and Management, Vol. 45, No. 2, 2003, pp. 278-293. doi:10.1016/S0095-0696(02)00058-X

[13] H. Wang, N. Mamingi, B. Laplante and S. Dasgupta, "Incomplete Enforcement of Pollution Regulation: Bargaining Power of Chinese Factories,” Environmental and Resource Economics, Vol. 24, No. 3, 2003, pp. 245-262. doi:10.1023/A:1022936506398

[14] S. J. DeCanio and W. E. Watkins, "Investment in Energy Efficiency: Do the Characteristics of Firms Matter?” The Review of Economics and Statistics, Vol. 80, No. 1, 1998, pp. 95-107. doi:10.1162/003465398557366

[15] H. Wang and D. "Wheeler, Financial Incentives and Endogenous Enforcement in China's Pollution Levy System,” Journal of Environmental Economics and Management, Vol. 49, No. 1, 2005, pp. 174-196. doi:10.1016/j.jeem.2004.02.004

[16] K. Fisher-Vanden, G. H. Jefferson, J. Ma and J. Xu, "Technology Development and Energy Productivity in China,” Energy Economics, Vol. 28, No. 5-6, 2006, pp. 690-705. doi:10.1016/j.eneco.2006.05.006

[17] H. Wang and Y. Jin, "Industrial Ownership and Environmental Performance: Evidence from China," Environmental and Resource Economics, Vol. 36, No. 3, 2007, pp. 255-273.

[18] N. Mamingi, S. Dasgupta, B. Laplante and J. H. Hong, "Understanding Firms' Environmental Performance: Does News Matter?” Environmental Economics and Policy Studies, Vol. 9, No. 2, 2008, pp. 67-79.

[19] S. Gupta and B. Goldar, "Do Stock Markets Penalize Environment-Unfriendly Behaviour? Evidence from India,” Ecological Economics, Vol. 52, No. 1, 2005, pp. 81-95. doi:10.1016/j.ecolecon.2004.06.011

[20] K. Elsayed and D. Paton, "The Impact of Environmental Performance on Firm Performance: Static and Dynamic Panel Data Evidence," Structural Change and Economic Dynamics, Vol. 16, No. 3, 2005, pp. 395-412. doi:10.1016/j.strueco.2004.04.004

[21] National Bureau of Statistics of China, "China Statistical Yearbook,” Beijing, 2007. 